\title{
Coal Handling Operational Risk Management: Stripped Overburden Transport in Brown Coal Open Pit Mines
}

\author{
Michal VANĚK ${ }^{1}{ }^{*}$, Gregorio Fidalgo VALVERDE ${ }^{2}$, Igor ČERNŸ \\ and Vlastimil HUDEC $\boldsymbol{E K}^{4}$
}

Authors' affiliations and addresses:

${ }^{1}$ VŠB - Technical University of Ostrava,

Faculty of Mining and Geology, Department of Economics and Control Systems, 17. listopadu

2172/15, 70800 Ostrava-Poruba, Czech

Republic

e-mail: michal.vanek@vsb.cz

${ }^{2}$ University of Oviedo, School of Mining, Energy and Materials Engineering of Oviedo, Business Management, St. Independencia, 13, 33004 Oviedo, Spain

e-mail: gfidaldo@uniovi.es

${ }^{3} \mathrm{VŠB}$ - Technical University of Ostrava, Faculty of Mining and Geology, Department of Economics and Control Systems, 17. listopadu 2172/15, 70800 Ostrava-Poruba, Czech Republic

e-mail: igor.cerny@vsb.cz

${ }^{4}$ VŠB - Technical University of Ostrava, Faculty of Mining and Geology, Department of Mining Engineering and Safety, 17. listopadu 2172/15, 70800 Ostrava-Poruba, Czech Republic

e-mail: vlastimil.hudecek@vsb.cz

\section{*Correspondence:}

Michal Vaněk, VŠB - Technical University of Ostrava, Faculty of Mining and Geology,

Department of Economics and Control Systems, 17. listopadu 2172/15, 70800

Ostrava-Poruba, Czech Republic

tel: +420596993336

e-mail: michal.vanek@vsb.cz

How to cite this article:

Vaněk, M., Valverde, G. F., Černý, I. and Hudeček, V. (2020). Coal Handling Operational Risk Management: Stripped Overburden Transport in Brown Coal Open Pit Mines. Acta Montanistica Slovaca, Volume 25 (2), 170-181

DOI:

https://doi.org/10.46544/AMS.v25i2.4

\begin{abstract}
This paper deals with the management of coal handling operational risks related to the transport of stripped overburden in giant brown coal pit quarries. It aims to identify and analyze the operational risks of currently applied continuous conveyance and to consider alternative transport, i.e., discontinuous transport. The Ishikawa diagram was used to identify the degree of operational risks affecting the net present value in both transport technologies. The operational risks examined were: human factor, suppliers, legislation, technology, environment, and market. Failure Mode and Effects Analysis was then used to evaluate the operational risks of continuous and discontinuous overburden transport technologies. The data for the analyses were obtained by means of a survey among experts in the field. The analyses show that the most significant operational risks of continuous transport are: lower demand for coal, an increase in the investment costs, conveyance breakdowns, the quality of the transported material, and work attitude. In the discontinuous technology, the identified operational risks were: increases in the cost of fuels, road maintenance and costs of tires, low-qualified labor; and work attitude. The comparison of the two examined technologies shows that discontinuous transport technology involves more operational risks than the continuous one.
\end{abstract}

\section{Keywords}

Coal handling, operational risk, brown coal, Ishikawa diagram, FMEA, stripped overburden transport. 


\section{Introduction}

Enterprises are exposed to many simultaneously emerging operational risks associated with individual decisions and actions. Despite a number of particularities, mining and processing of mineral resources is a standard business activity. This means that a mining company management aims for profit, increases in the company's market value, and other goals they should outline. According to Shenkir and Walker (2006), in the 21 st century, the technology advancements, such as the internet and global competition, brought a number of operational risks to different companies. These include the use of complex financial instruments, deregulations, downsizing, and consumer demands (Shenkir and Walker, 2006).

To reach their goals, managers need to decide on specific steps and measures of both strategic and operational character. Taking the right decision requires experience and relevant information (Kozel, 2017). In the case of investment decisions, managers may not have the courage to make tough decisions. When making decisions and choosing from possible options or alternatives, managers should rely on the results of various analyses. When decisions need to be supported by investment, studies providing information to answer questions on the effectiveness and return on investment are vital.

Despite being standard businesses, companies in the mining industry face many forms of operational risks, such as government policies, environmental incidents, survival circumstances and market threats (Van Thueyet et al., 2007). Similarly to making decisions on the basis of analyses, operational risks should be managed effectively through their analyses, thus affecting the company value.

Although the operational risk is already included in the economic evaluation of an investment, its analysis may foreshadow significant sources of risk and their possible impacts on the investment in question. No doubt, it is valuable for a manager to be aware of the interval in which the values of the selected economic criterion, for example, net present value (NPV), may range. The awareness of operational risks helps responsible managers to focus on measures in order to reduce or eliminate them.

Surface mining systems comprise a number of stripping, mining, back-filling, and auxiliary works and operations, which are implemented in the most diverse geological and deposition conditions. They also use different technologies and equipment. Mining exploitation includes four basic stages, namely, excavation, loading, transportation, and processing (Singh, 2004; Rahimdel and Bagherpour, 2016). This article does not deal with all the stages, focusing only on the transport of the stripped overburden.

The major function of the so-called technological transport is to move the stripped overburden into dumps, heaps or into settling basins, and to transport the useful materials to further processing or directly to the client (Slivka et al., 2002). It comprises the transport equipment and supplementary and auxiliary mechanization, including the means of control. Something characteristic of these transport systems are the conditions under which the transport routes constantly change, alternating loading and unloading points when dealing with steep slopes, various discharge ends and long distances (Singh, 2004), (Mikoláš et al., 2011). A good choice of suitable load transport undoubtedly belongs to the areas that contribute to the general economic success of a mining company.

Although long-distance belt transport is solely used in the Czech giant brown coal pit quarries to transport the stripped overburden, it may be interesting for mine owners that discontinuous transport brings a comparative advantage as opposed to the continuous conveyance. For example, Seidl et al. (2011) state that in contrast to continuous conveyance the use of rubber-tired haulage ensures stability in time and bigger capacity of exploitation, it is mobile in prioritizing the different mining horizons, there is no need to build costly and difficult working floors, and it is more economical as a complementary technology after mining. Despite the threats, such as the costs of services, repairs, fuel, and capital expenditure, rubber-tired haulage appears optimal for the extraction of residual reserves of coal substance (Seidl et al., 2011).

The study by Seidl et al. (2011) also implies that from an economic perspective, both the overburdened transport technologies (continuous and discontinuous) are sustainable. However, the study did not deal with the operational risks that the transport options are related to. As the economic assessment of the technological options is not enough, this article aims to put through operational risk analysis the two transport technologies and to identify whether the alternatives are comparable as for their degree of risk.

Despite the fact that continuous technology has long been used in Czech brown coal open pit mines and discontinuous technology is a considered alternative. It is possible to ask a research question which of the two alternatives is less risky.

Current literature provides mixed empirical evidence and arguments on the relationships between enterprise risk management and company performance. Some studies focus on enterprise risk management in general (Lai and Shad, 2017; Soomro and Lai, 2017; Meidell and Kaarbøe, 2017). Others deal with risks related to investments (Juchniewicz, 2016; Cehlar et al., 2011). Some authors also report research on specific industries, including the mining industry (Toraño et al., 2012; Badri et al., 2013; Tworek et al., 2018; Sabanov et al., 2008; Bijańska, 2016; Chinbat, 2012). 
This article focuses on the risks related to the transport of stripped overburden in giant pit quarries in the Czech Republic. The results may be applied by managers of analogous giant pit quarries or in other fields. It compares the operational risks of two technological solutions to transport stripped overburden: continuous transport technology and, as an alternative, discontinuous transport technology, giving the basis for quality decision making. Results show that there may be antagonist relationships between the values characterizing the operational risk and economic efficiency. When deciding on the choice of the technological solution, this makes the decision-making more difficult. Therefore, risks must be identified and assessed using well-selected methods. When evaluating the economic efficiency of an investment project, in particular, it is important to develop an adequate projection of operational risks.

\section{Methods and materials}

A risk is defined as the combination of frequency, probability, and consequences of a specific dangerous situation or event, according to the updated standard on risk management (ISO 31000:2018). It can also be defined as a chance that something will happen and that it will have an impact on a facility (Petrovic et al., 2014). Risk, according to the same standard, is presented as the combination of potential events and consequences associated with the probability of its occurrence. The systematic use of information in order to identify the sources and to estimate the risk is defined as the risk analysis (ISO 31000:2018). Risk analysis provides the basis to assess the risk level, the treatment, and the acceptability of a risk (Petrovic et al., 2014).

The point of departure for the operational risk assessment of the transport options in the conditions of a brown coal opencast mine was the ISO 31000:2018. As the standard outlines a generic approach and can be used within different contexts, for example, environmental risks (Krzemień et al., 2016), it was necessary to adjust the approach for the specific issue under solution. This means that the principles and framework of the risk management architecture were not considered, and the risk management was reduced to the process alone. According to the standard, the risk management process has the following parts: (i) communication and consultation, (ii) determination of the context, (iii) risk assessment, and (iv) risk management.

This paper is focused on the risk assessment, which breaks into the following phases: (i) identification of risks, (ii) risk analysis, and (iii) risk rating.

ISO 31000:2018 is only a conceptual framework for risk management. The standard does not render any specific techniques or tools to be applied in the given conditions or situations. Therefore, the IEC/ISO 31010:2009 on risk management and risk assessment techniques should be consulted.

Risk assessment is the main step in risk management. Risk assessment is the overall process of risk identification, risk analysis, and risk evaluation. It should be conducted systematically, iteratively, and collaboratively, drawing on the knowledge and views of stakeholders. It should use the best available information, supplemented by further inquiry as necessary.

Once this procedure has been carried out, risk management instruments and risk controls can be selected. The results of risk assessment, therefore, affect the scope and intensity of protection. According to Nawrocki and Jonek-Kowalska (2016), the "holistic identification of risk sources" is an extremely important element in risk assessment, being related to all areas of the enterprise's business and its environment (Nawrocki and JonekKowalska, 2016).

Risk assessment may be carried out at various depths and details using one or several methods, either simple or more complex ones. The form of risk assessment and its output should comply with the risk criteria developed as parts of context determination (IEC/ISO 31010:2009).

To assess risks, the standard offers 31 tools and techniques to choose from. In this article about continuous and discontinuous transport of the stripped overburden, two major methods were applied: (i) Cause-and-effect analysis for risk identification and (ii) Failure Models and Effects Analysis (FMEA) for risk analysis and evaluation.

Focusing on the transport of the stripped overburden from the point of extraction to the disposal site, either internal or external spoil heap, belt transport is used in case of continuous conveyance, being an inseparable part of the whole mining complex. Concerning this transport, usually, rubber-tired haulage is used. In giant pit quarries with discontinuous conveyance, they usually use trucks with a working load from $12-50 \mathrm{t}$, the socalled dumpers. Apart from dumpers, there are also dozers, tanks, spray dampers, etc.

\section{Risk identification: Cause-and-effect analysis.}

Following ISO 31000 (2018), the first step in risk assessment is risk identification, whose purpose is to find, recognize, and describe risks that might help or prevent an organization from achieving its objectives. Relevant, appropriate, and up-to-date information is important in identifying risks. It is a structured method to identify possible causes of undesirable events or problems and used to classify the possible contributing factors into extensive categories. The information is plotted either into a fishbone diagram (Ishikawa diagram), or a tree diagram (IEC/ISO 31010:2009). 
The cause-and-effect analysis renders a structured representation of a list of causes for a specific effect in the form of an image. The cause-and-effect analysis should be performed by a team of experts well aware of the problem requiring solutions. The IEC/ISO 31010:2009 describes the basic steps in the cause-and-effect analysis.

Lehman et al. (1998) generally consider the research process as a series of 10 steps: (1) problem definition, (2) determining information needs, (3) setting research objectives, (4) selection of type of research, (5) design of data collection, (6) development of a plan of analysis, (7) data collection, (8) analysis, (9) drawing conclusions and (10) reporting.

Experts in the field were consulted by means of a two questionnaires survey in order to evaluate or supplement the undesirable events or problems that will drive to a decrease in the Net Present Value (NPV) of the considered technologies.

The NPV was used for the economic evaluation of the assessed technologies, Seidl et al. (2011), the NPV was determined as the head of the Ishikow diagram. This choice was also supported by the fact that the threats considered negatively affect the value of the causal attributes of NPV.

Based on Lehman et al. (1998), Aaker et al. (2003), and Malhotra (2010), no hypotheses were stated as the purpose of the research was to obtain experts' opinions and statements on the given problem.

The first questionnaire dealt with continuous conveyance, and the second questionnaire dealt with discontinuous transport technology. Questionnaires you can see at https://data.mendeley.com/drafts/2vcv8tcpjd. Both questionnaires included seven major risk categories, consisting of specific risks: human factor, supplier, legislation, technology, costs, environment, and market, based on the work developed by (Vaněk et al., 2012). The seven major risk categories are based on the analysis of the macro- and micro-economic environment of the business. According to Janíček (2013), an ideal expert team should have 5- 7 members and should include respondents from various levels of the company management. The specific risks were identified using Ishikawa diagrams by the authors' team and five experts from the management of coal companies.

By applying the cause-and-effect analysis, it is possible to identify a rather high number of risk sources. These risk sources are later evaluated using the FMEA analysis.

\section{Risk analysis: Failure Mode and Effects Analysis.}

The second step in risk assessment, according to ISO 31000 (2018), is risk analysis, which purpose is to comprehend the nature of risk and its characteristics, including, where appropriate, the level of risk. Risk analysis involves a detailed consideration of uncertainties, risk sources, consequences, likelihood, events, scenarios, controls, and their effectiveness. An event can have multiple causes and consequences and can affect multiple objectives.

Failure Mode and Effects Analysis (FMEA) is one of the structured, systematic, and proactive techniques used in failure analysis. The purpose of FMEA is to list out all possible failure modes and evaluate their causes as well as their subsequent effects on the performance of the system under consideration (Bozdag et al., 2015).

According to Nicholas and Steyn (2012), FMEA is used to determine the ways a technical system may fail, as well as how the effects of failure may affect the system's performance, safety, and environment. The model measures the risk level by means of a risk priority number (RPN), a semi-quantitative criticality measure computed by multiplying the severity, the probability of occurrence and the likelihood of detection, of each potential failure mode, using rates from 1 to 10, like the one described in Tab. 1 (Bozdag et al., 2015).

Tab. 1. Severity, probability of occurrence and likelihood of detection scales

\begin{tabular}{|c|c|c|c|}
\hline Rating & Severity & Probability of occurrence & Likelihood of detection \\
\hline 10 & Hazardous without warning & Extremely high & Absolute uncertainly \\
\hline 9 & Hazardous with warning & Very high & Very remote \\
\hline 8 & Very high & Repeated failures & Remote \\
\hline 7 & High & High & Very low \\
\hline 6 & Moderate & Moderately high & Low \\
\hline 5 & Low & Moderate & Moderate \\
\hline 4 & Very Low & Relatively low & Moderately high \\
\hline 3 & Minor & Low & High \\
\hline 2 & Very minor & Remote & Very high \\
\hline 1 & Almost none & Nearly impossible & Almost certain \\
\hline
\end{tabular}

To ensure as objective inputs as possible, experts in the field were also consulted. Considering the issue under interest, a low number of respondents were expected.

The fundamental difference in the degree of risk in the observed technologies will lay in the RPN interval and in the difference of modus. Potential failure modes are then categorized by the RPN; the highest RPNs have the highest priority (Nicholas, 2012). 


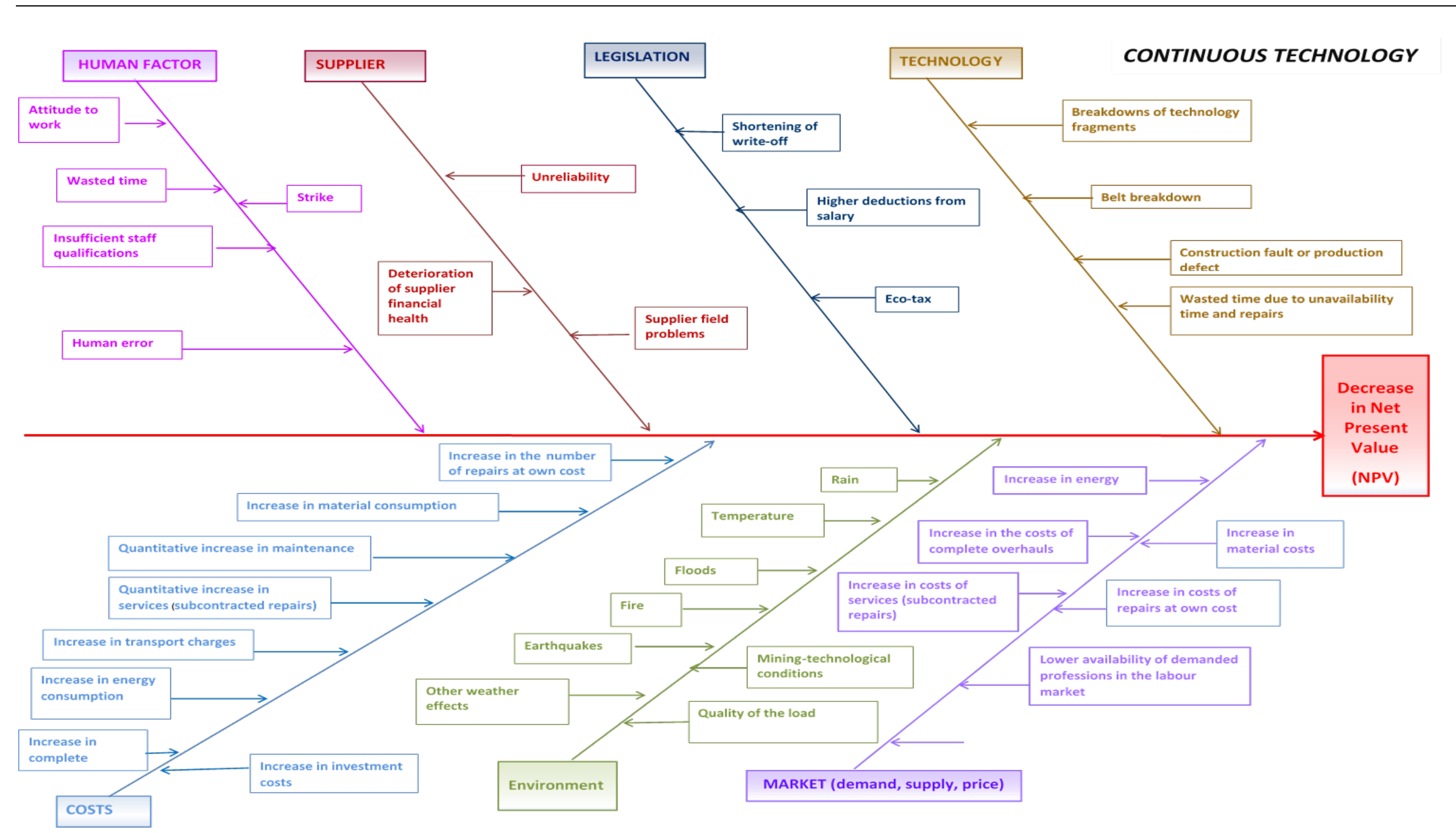

Fig. 1. Ishikawa diagram for continuous technology. Source: own processing. 


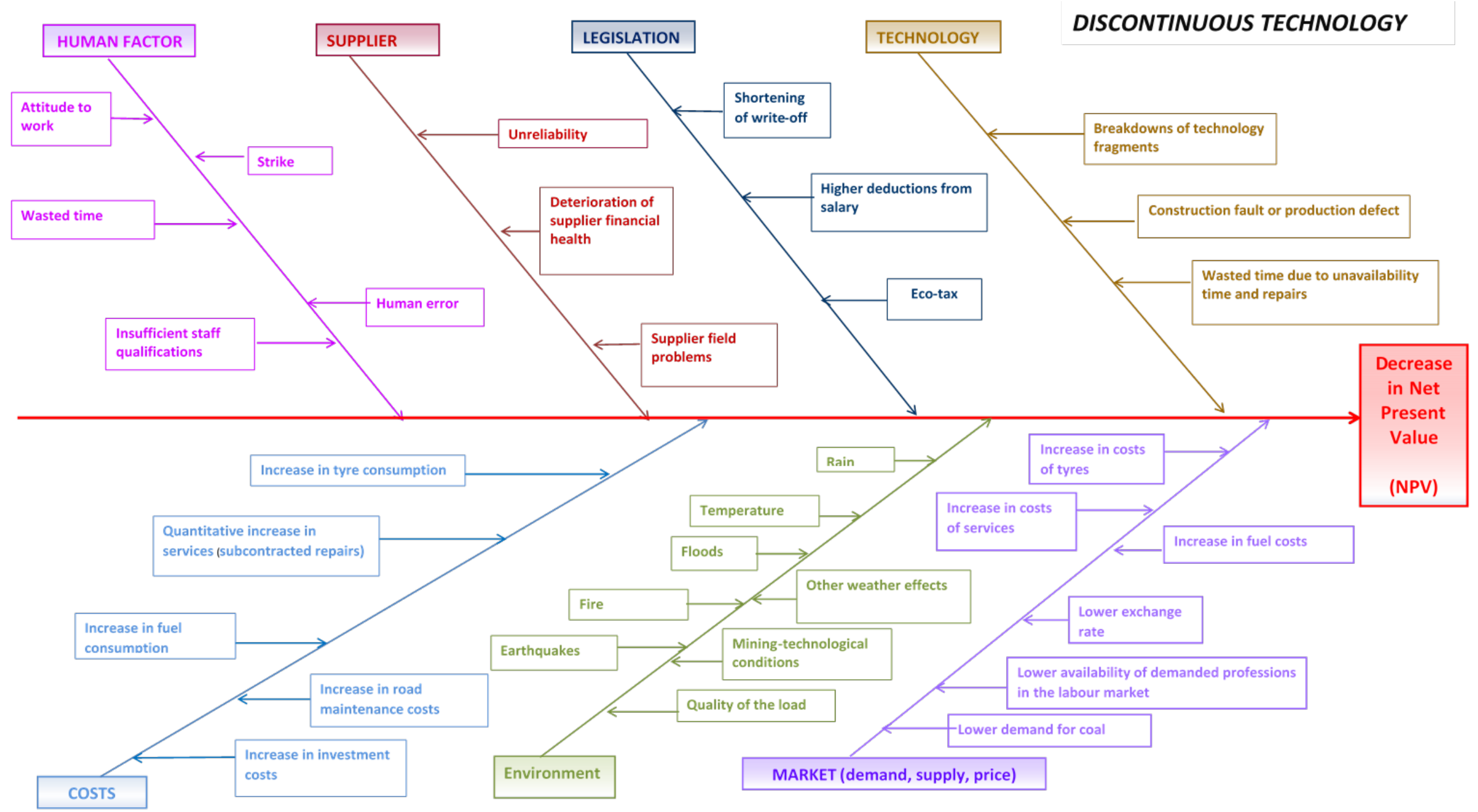

Fig.2. Ishikawa diagram for discontinuous technology. Source: own processing 


\section{Results}

The first step in the process of risk assessment of the stripped overburden transport options is to identify the risks. Risks were identified using the cause-and-effect analysis (Ishikawa diagram). After making this analysis, it was presented to experts in the field in order to obtain their review. The final form of the analysis, which became the starting point for the subsequent risk analysis, is presented in Fig. 1 (continuous technology) and Fig. 2 (discontinuous technology).

The risk analysis was carried out by means of FMEA. In order to obtain an objective evaluation of the transport option risks, we also addressed experts in the field. Considering the uniqueness of the field, we consider the number of respondents sufficient. In line with the methodology, from the obtained values the modus for severity, probability, and detectability of the risk was calculated and, subsequently, the value of RPN, that are presented for the continuous transport technology (Tab. 2) and the discontinuous transport technology (Tab. 3).

Tab.2. RPN for the continuous transport technology

\begin{tabular}{|c|c|c|c|c|c|c|}
\hline $\begin{array}{c}\text { Area } \\
\text { of risk }\end{array}$ & Type of risk & Severity & Probability & Detectability & RPN & $\begin{array}{l}\mathrm{RPN} \\
{[\%]} \\
\end{array}$ \\
\hline \multirow{5}{*}{ 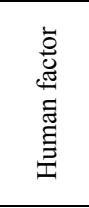 } & Attitude to work & 9 & 7 & 5 & 315 & 5.7 \\
\hline & Wasted time & 9 & 5 & 2 & 90 & 1.6 \\
\hline & Human error & 7 & 4 & 2 & 56 & 1.0 \\
\hline & Insufficient staff qualifications & 9 & 1 & 9 & 81 & 1.5 \\
\hline & Strike & 10 & 1 & 1 & 10 & 0.2 \\
\hline \multirow{3}{*}{ 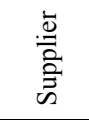 } & Unreliability & 9 & 3 & 2 & 54 & 1.0 \\
\hline & Deterioration of supplier financial health & 7 & 3 & 2 & 42 & 0.8 \\
\hline & Supplier field problems & 7 & 5 & 2 & 70 & 1.3 \\
\hline \multirow{3}{*}{ 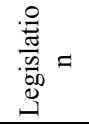 } & Shortening of write-off period & 9 & 6 & 1 & 54 & 1.0 \\
\hline & Higher deductions from salary & 4 & 2 & 9 & 72 & 1.3 \\
\hline & Eco-tax & 9 & 4 & 1 & 36 & 0.7 \\
\hline \multirow{4}{*}{ 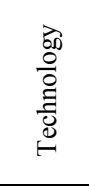 } & Breakdowns of technology fragments & 6 & 5 & 9 & 270 & 4.9 \\
\hline & Belt breakdown & 10 & 6 & 6 & 360 & 6.6 \\
\hline & Construction fault or production defect & 9 & 5 & 4 & 180 & 3.3 \\
\hline & $\begin{array}{l}\text { Wasted time due to unavailability time and } \\
\text { repairs }\end{array}$ & 7 & 3 & 10 & 210 & 3.8 \\
\hline \multirow{8}{*}{$\begin{array}{l}\tilde{n} \\
0 \\
0\end{array}$} & Increase in complete overhauls & 7 & 1 & 3 & 21 & 0.4 \\
\hline & $\begin{array}{l}\text { Increase in the number of repairs at own } \\
\text { cost }\end{array}$ & 8 & 6 & 5 & 240 & 4.4 \\
\hline & Increase in material consumption & 8 & 5 & 6 & 240 & 4.4 \\
\hline & $\begin{array}{l}\text { Quantitative increase in services } \\
\text { (subcontracted repairs) }\end{array}$ & 4 & 2 & 3 & 24 & 0.4 \\
\hline & Increase in transport charges & 6 & 6 & 2 & 72 & 1.3 \\
\hline & Increase in energy consumption & 8 & 7 & 1 & 56 & 1.0 \\
\hline & Quantitative increase in maintenance & 8 & 7 & 4 & 224 & 4.1 \\
\hline & Increase in investment costs & 10 & 7 & 6 & 420 & 7.7 \\
\hline \multirow{8}{*}{ 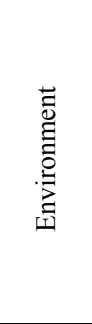 } & Floods & 10 & 2 & 1 & 20 & 0.4 \\
\hline & Earthquakes & 10 & 1 & 1 & 10 & 0.2 \\
\hline & Fire & 10 & 2 & 1 & 20 & 0.4 \\
\hline & Temperature & 9 & 4 & 1 & 36 & 0.7 \\
\hline & Rain & 8 & 5 & 5 & 200 & 3.6 \\
\hline & Quality of the load & 8 & 8 & 5 & 320 & 5.8 \\
\hline & Other weather effects & 8 & 1 & 1 & 8 & 0.1 \\
\hline & Mining-technological conditions & 7 & 5 & 3 & 105 & 1.9 \\
\hline \multirow{7}{*}{ 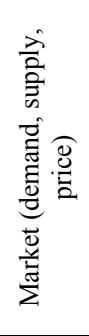 } & $\begin{array}{c}\text { Increase in costs of services (subcontracted } \\
\text { repairs) }\end{array}$ & 8 & 7 & 1 & 56 & 1.0 \\
\hline & Increase in the costs of complete overhauls & 7 & 7 & 4 & 196 & 3.6 \\
\hline & Increase in energy costs & 9 & 6 & 1 & 54 & 1.0 \\
\hline & Increase in costs of repairs at own cost & 7 & 7 & 6 & 294 & 5.4 \\
\hline & Lower demand for coal & 9 & 7 & 8 & 504 & 9.2 \\
\hline & Increase in material costs & 8 & 7 & 3 & 168 & 3.1 \\
\hline & $\begin{array}{l}\text { Lower availability of demanded } \\
\text { professions in the labor market } \square\end{array}$ & 7 & 6 & 5 & 210 & 3.8 \\
\hline
\end{tabular}

Source: own processing 
Tab.3. RPN for the discontinuous transport technology

\begin{tabular}{|c|c|c|c|c|c|c|}
\hline $\begin{array}{c}\text { Area } \\
\text { of risk }\end{array}$ & Type of risk & Severity & Probability & Detectability & RPN & $\begin{array}{c}\mathrm{RPN} \\
{[\%]}\end{array}$ \\
\hline \multirow{5}{*}{ 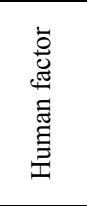 } & Attitude to work & 9 & 8 & 5 & 360 & 6.6 \\
\hline & Wasted time & 9 & 4 & 5 & 180 & 3.3 \\
\hline & Human error & 9 & 3 & 3 & 81 & 1.5 \\
\hline & Insufficient staff qualifications & 9 & 6 & 10 & 540 & 9.9 \\
\hline & Strike & 10 & 1 & 1 & 10 & 0.2 \\
\hline \multirow{3}{*}{ 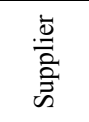 } & Unreliability & 8 & 1 & 1 & 8 & 0.1 \\
\hline & Deterioration of supplier financial health & 6 & 2 & 1 & 12 & 0.2 \\
\hline & Supplier field problems & 7 & 3 & 5 & 105 & 1.9 \\
\hline \multirow{3}{*}{ 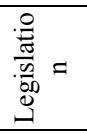 } & Shortening of write-off period & 9 & 5 & 5 & 225 & 4.1 \\
\hline & Higher deductions from salary & 5 & 2 & 9 & 90 & 1.6 \\
\hline & Eco-tax & 6 & 5 & 1 & 30 & 0.5 \\
\hline \multirow{3}{*}{ 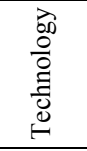 } & Breakdowns of technology fragments & 5 & 5 & 5 & 125 & 2.3 \\
\hline & Construction fault or production defect & 5 & 2 & 3 & 30 & 0.5 \\
\hline & $\begin{array}{l}\text { Wasted time due to unavailability time and } \\
\text { repairs }\end{array}$ & 9 & 6 & 5 & 270 & 4.9 \\
\hline \multirow{5}{*}{ 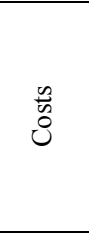 } & Increase in tire consumption & 8 & 10 & 3 & 240 & 4.4 \\
\hline & $\begin{array}{c}\text { Quantitative increase in services } \\
\text { (subcontracted repairs) }\end{array}$ & 8 & 2 & 4 & 64 & 1.2 \\
\hline & Increase in fuel consumption & 10 & 8 & 1 & 80 & 1.5 \\
\hline & Increase in investment costs & 8 & 5 & 1 & 40 & 0.7 \\
\hline & Increase in road maintenance costs & 9 & 9 & 9 & 729 & 13.4 \\
\hline \multirow{8}{*}{ 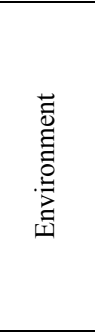 } & Floods & 10 & 2 & 1 & 20 & 0.4 \\
\hline & Earthquakes & 10 & 1 & 1 & 10 & 0.2 \\
\hline & Fire & 9 & 2 & 1 & 18 & 0.3 \\
\hline & Temperature & 3 & 2 & 1 & 6 & 0.1 \\
\hline & Rain & 9 & 4 & 1 & 36 & 0.7 \\
\hline & Quality of the load & 8 & 3 & 4 & 96 & 1.8 \\
\hline & Other weather effects & 3 & 2 & 1 & 6 & 0.1 \\
\hline & Mining-technological conditions & 8 & 8 & 1 & 64 & 1.2 \\
\hline \multirow{6}{*}{ 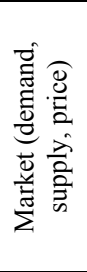 } & Increase in costs of services & 7 & 5 & 1 & 35 & 0.6 \\
\hline & Increase in costs of tires & 10 & 8 & 9 & 720 & 13.2 \\
\hline & Increase in fuel costs & 9 & 10 & 9 & 810 & 14.8 \\
\hline & $\begin{array}{l}\text { Lower availability of demanded professions } \\
\text { in the labor market }\end{array}$ & 6 & 7 & 6 & 252 & 4.6 \\
\hline & Lower exchange rate & 9 & 6 & 1 & 54 & 1.0 \\
\hline & Lower demand for coal & 10 & 8 & 2 & 160 & 2.9 \\
\hline
\end{tabular}

Source: own processing

The significance of the different risks is clearly presented in Fig. 3 (continuous transport technology) and Fig. 4 (discontinuous transport technology).

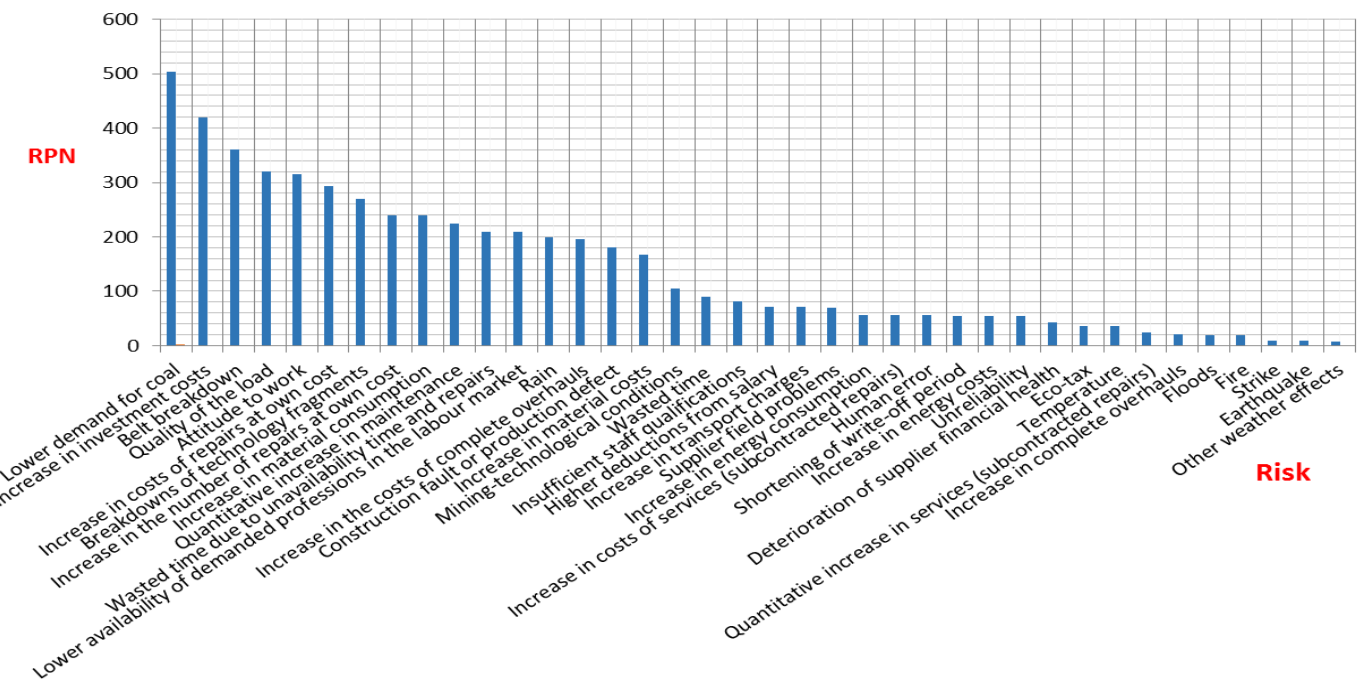

Fig. 3. Risk pattern of continuous transport technology, according to RPN. Source: own processing 


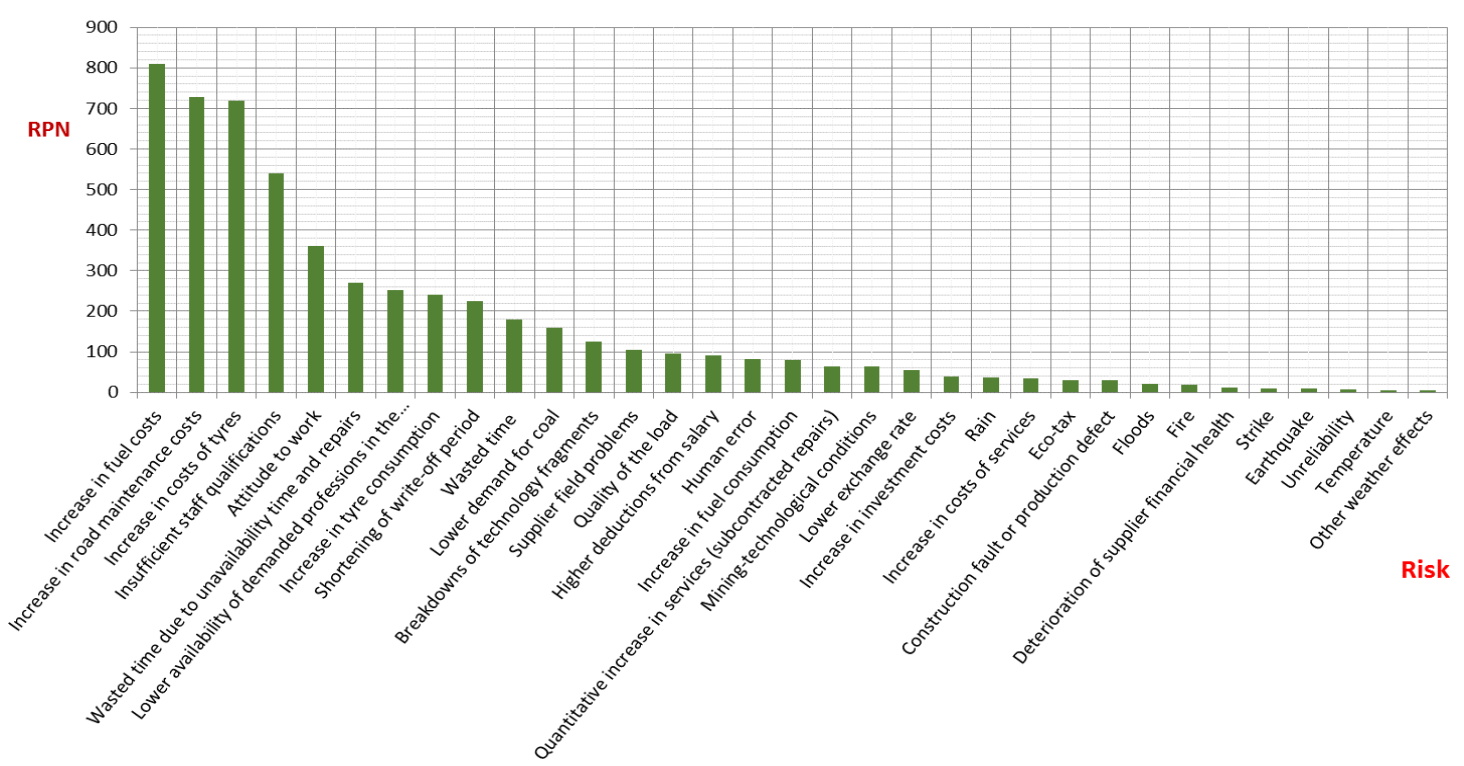

Fig. 4. Risk pattern of discontinuous transport technology, according to RPN. Source: own processing

\section{Discussion}

The transport of the stripped overburden during large-scale surface mining of mineral products belongs to the key processes that cardinally influence the overall exploitation of the mineral under interest. Therefore, the choice of transport cannot be underestimated.

Tab. 4 gives the riskiest factors (top five) based on Pareto's analysis in the considered transport alternatives.

It is apparent from Tab. 4 that the top four risks in the discontinuous technology are higher than the most severe risk in continuous technology.

Tab. 4. Comparison of the top five most significant risks.

\begin{tabular}{|c|c|c|c|}
\hline \multicolumn{2}{|c|}{ Continuous technology } & RPN & Discontinuous technology \\
\hline Item & 504 & Increase in costs of fuel & RPN \\
\hline Lower demand for coal & 420 & Increase in road maintenance costs & 729 \\
\hline Increase in investment costs & 360 & Increase in costs of tires & 720 \\
\hline Belt breakdown & 320 & Insufficient staff qualifications & 540 \\
\hline Load quality & 315 & Attitude to work & 360 \\
\hline Attitude to work
\end{tabular}

Those risks are also specific for this transport technology. They are operational risks and, thus, principally contribute to the overall degree of risk of the technological option under consideration. The occurrence of such risks in practice brings an increase in the costs of operation and, thus, lower cash flow from the investment and a fall in the net present value.

Although input data generated based on brainstorming are subjective, it is useful to distinguish between RPN of continuous and discontinuous transport technology by descriptive statistics (see Table 5).

Tab. 5. Distinguish between RPN of continuous and discontinuous transport technology

\begin{tabular}{|c|c|c|}
\hline Item & Continuous transport & Discontinuous transport \\
\hline Total number of identified risks & 38 & 33 \\
\hline RPN range & $496(8-504)$ & $804(6-810)$ \\
\hline The risk median & 76.5 & 80.0 \\
\hline The average value of the risk & 142 & 166 \\
\hline The variance of the value & 16,114 & 48,069 \\
\hline The coefficient of variation & 0.8936 & 1.314 \\
\hline
\end{tabular}

Source: own processing 
Figure 5 shows the distribution of risks in the observed transport technologies. It implies that the risk pattern is analogous to both the technologies. The highest number of risks concentrates in the third quartile. The third quartile of the continuous technology includes $23.68 \%$ of risks and $27.27 \%$ of risks in the discontinuous one. The range of RPN in the third quartile of the continuous technology is 144 , and in the discontinuous technology, it is 145 .

It is also clear from Figure 5 that the fundamental difference in the degree of risk in the observed technologies lies in the RPN interval and the difference in the maximum values of RPN.

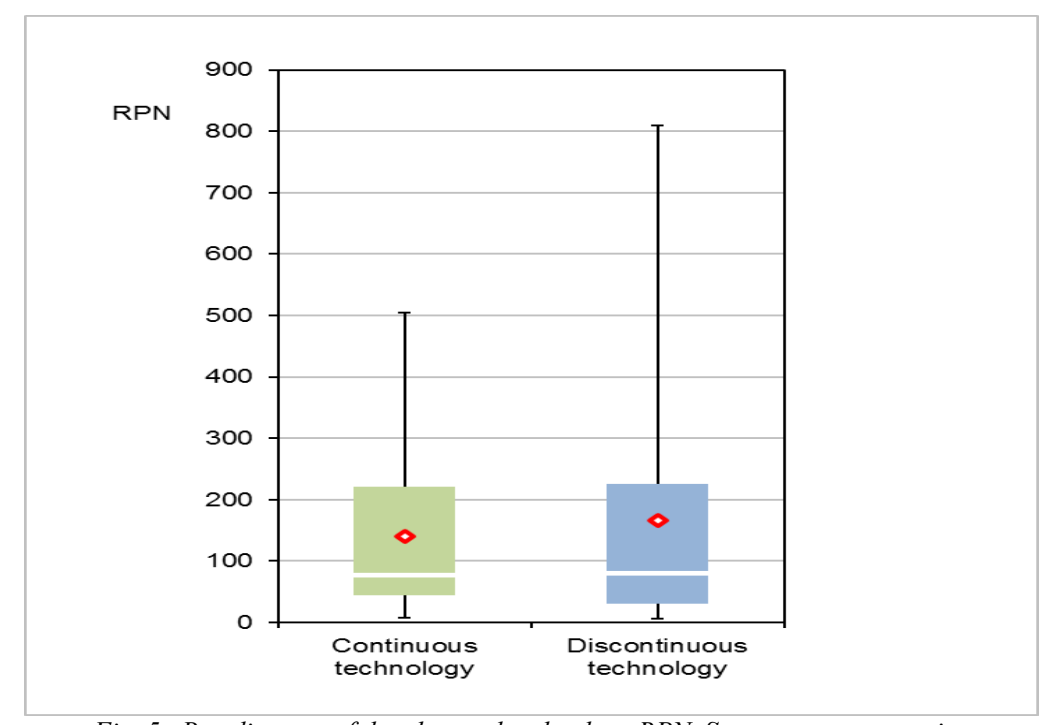

Fig. 5. Box diagram of the observed technology RPN. Source: own processing

The data, as mentioned above, imply that the continuous transport technology shows a 306-point-lower RPN value than the discontinuous one. The discontinuous technology also has a higher risk range, i.e., of 308. This state is caused by four of the most important risks (increase in costs of fuel - RPN 810, increase in road maintenance costs - RPN 729, increase in costs of tires - RPN 720, insufficient staff qualifications - RPN 540).

Figure 5 shows that the risk of both transport technology is almost the same from the large part. However, from a complexity point of view, the data lead to an unambiguous conclusion that the existing continuous technology is less risky than the discontinuous one.

In contrast to the study by Vaněk et al. (2013), using different methods and stating that both the transport technologies are more or less equivalent as for the level of risks involved, the results of the FMEA herein partly disagree. Vaněk et al. (2013) considered the technologies by means of the probability distribution of NPV, while the probability distribution of the evaluation indicator was implemented via scenarios and statistical characteristics (variance, standard deviation, variation coefficient). The risks discussed in Vaněk et al. (2013) were the results of sensitivity analysis. This analysis works only with risks quantified in monetary units. Therefore, it does not cover the whole range of risks.

The methods applied in the research herein enabled us to identify and subsequently analyze a much wider spectrum of risks, and thus offer a more complex view on the issue.

\section{Conclusion}

Risk analyses may be carried out using a number of approaches and applying several analytical methods. The choice of the approach or method depends on the purpose of the analysis.

In this case, the purpose of the analysis lay in the assessment of two technological options which may be used to transport the stripped overburden in the giant pit quarries. However, the analysis may serve as the starting point to frame the measures to be implemented within the risks management phase.

Risk identification was carried out by means of a Cause-and-effect analysis, taking into account seven major risk categories (human factor, supplier, legislation, technology, costs, environment, and market), based on the work developed by (Vaněk et al., 2012). The seven major risk categories are based on the analysis of the macro- and micro-economic environment of the business, and addressing a possible decrease in the Net Present Value (NPV) of the considered technologies.

The risk analysis was carried out using the FMEA analysis. The analysis implies that discontinuous technology involves more risks than continuous conveyance. This finding is also the answer to the research question asked by the authors in the Introduction. However, the higher degree of risk in discontinuous technology does not necessarily mean that it cannot be used when deciding on overburden transport technology. 
Risk assessment is only a partial assessment. To make a qualified assessment of the technological alternatives, complex approaches must be taken.

By complex approaches, i.e., economic, environmental, etc., the anticipation of risks in the technological options all the way to the discount rate value should be considered. A difference in the discount rate value may thus render a more objective evaluation of the whole economy of the stripped overburden transport in the long run.

The results may be applied by managers of analogous giant pit quarries or in other fields. The knowledge obtained is influenced by the number of localities where brown coal is currently exploited in the Czech Republic. Although the article contributes to filling the gap of knowledge about the risks of technologies used to transport overburden in giant open-pit mines, it is necessary to provide further research. The research should focus on the complex assessment of the economic efficiency of the stripped overburden transport technologies, as well as the possibilities of using other risk analysis methods.

\section{References}

Aaker, D.A., Kumar, V. and Day, G.S. (2004). Marketing research. 8th ed. Hoboken: Wiley.

Badri, A., Nadeau, S. and Gdobossou, A. (2013). A new practical approach to risk management for underground mining project in Quebec. Journal of Loss Prevention in the Process Industries [online]. 26, 1145-1158. $\begin{array}{llllll}\text { [Viewed } & 10 & \text { February } & \text { 2019]. }\end{array}$ https://www.sciencedirect.com/science/article/pii/S0950423013001162

Bijańska, J. (2016). Risk management of activating and mining of a longwall in a coal mine. Zeszyty naukowe Politechniki Śląskiej; seria: Organizacja i zarządzanie [online]. 91, 61 - 73. [Viewed 20 January 2019]. Available from: http://yadda.icm.edu.pl/yadda/element/bwmeta1.element.baztech-10f6ebe5-631f-443e97a1-247570a96cdb

Bozdag, E., Asan, U., Soyer, A. and Serdarasan, S. (2015). Risk prioritization in Failure Mode and Effects Analysis using intervaltype-2 fuzzy sets. Expert Systems with Applications [online]. 42, 4000-4015. $\begin{array}{lllll}\text { [Viewed } 20 & \text { January } & \text { 2019]. }\end{array}$ https://www.sciencedirect.com/science/article/pii/S0957417415000305

ISO 31000:2018. Risk Management - Principles and guidelines. International Organization for Standardization.

IEC/ISO 31010:2009. Risk management - Risk assessment techniques. International Electrotechnical Commission / International Organization for Standardization.

Cehlár, M. Teplická, K. and Senová, A. (2011). Risk management as instrument for financing projects in mining industry. In: 11th International Multidisciplinary Scientific GeoConference SGEM 2011: Conference Proccedings Volume 1 Surveying Geology \& Mining Ecology Management, 20 - 25 June 2011, Albena. Sofia: STEF92 Technology Ltd., 913-920.

Chinbat, U. (2012). Risk Analysis in the Mining Industry. In: M. Savino, ed. Risk Management in Environment, Production and Economy [online]. Rijeka: InTech, pp 103-122. [Viewed 22 February 2019]. Available from: https://www.intechopen.com/books/risk-management-in-environment-production-andeconomy/risk-analysis-in-the-mining-industry

Janíček, P. and Marek, J. (2013). Expertní inženýrství v systémovém pojetí. Praha: Grada Publishing.

Juchniewicz, M. (2016). Review and comparative analysis of project risk management concept. Research papers of Wrocław university of economics [online]. 421, 216-228. [Viewed 3 March 2019]. Available from: http://eds.b.ebscohost.com/eds/pdfviewer/pdfviewer?vid=0\&sid=fla2daf6-a1ad-4c7f-baefa0e09cd7c781\%40sessionmgr 103

Kozel, R., Vilamová, Š, Baránek, P., Friedrich, V., Hajduová, Z., Behún, M. (2017). Optimizing of the Balanced Scorecard Method for Management of Mining Companies with the Use of Factor Analysis. Acta Montanistica Slovaca [online]. 22 (4), 439-447. [Viewed 28 January 2019]. Available from: https://actamont.tuke.sk/pdf/2017/n4/11 kozel.pdf

Krzemień, A., Suárez Sánchez, A., Riesgo Fernández, P., Zimmermann K and González Coto, F. (2016). Towards sustainability in underground coal mine closure contexts: A methodology proposal for environmental risk management. Journal of Cleaner Production [online]. 139., 1044-1056. [Viewed 14 February 2019]. Available from: https:/www.sciencedirect.com/science/article/pii/S0959652616313130

Lai, F.W. and Shad, K. (2017). Economic value added analysis for enterprise risk management. Global Business and Management Research: An International Journal [online]. 9(1), 338-347. [Viewed 14 February 2019]. Available from: https://www.researchgate.net/publication/318129580_Economic_Value_Added_Analysis_for_Enterprise Risk_Management

Lehmañn, D.R.R., Gupta, S. and Steckel, J. H. (1998). Marketing research. Reading MA: Addison-Wesley.

Malhotra, N.K. (2010). Marketing research: an applied orientation, sixth ed. Boston: Pearson. 
Meidell, A., Kaarbøe, K. (2017). How the enterprise risk management function influences decision-making in the organization - A field study of a large, global oil and gas company. The British Accounting Review [online]. 49, 39-55. [Viewed 19 February 2019]. Available from: https://www.sciencedirect.com/science/article/pii/S0890838916300439

Mikoláš, M., Vaněk, M., Černý, I., Kučerová, L. and Žoček, F. (2011) Economic modelling under conditions of exploitation of cohesive construction minerals. Acta Universitatis Agriculturae et Silviculturae Mendelianae Brunensis [online]. 59(7), 249 - 260. [Viewed 10 January 2019]. Available from: https://acta.mendelu.cz/media/pdf/actaun_2011059070249.pdf

Nawrocki, T.L. and Jonek-Kowalska, I. (2016). Assessing operational risk in coal mining enterprises - Internal, industrial and international perspectives. Resources Policy [online]. 48, 50-67. [Viewed 14 February 2019]. Available from: https://www.sciencedirect.com/science/article/pii/S0301420716300137

Nicholas, J.M. and Steyn, H. (2012). Project management for engineering, business and technology, fourth ed. London: Routledge.

Petrovic', D.V., Tanasijevic', M., Milic', V., Lilic', N., Stojadinovic', S. and Svrkota, I. (2014). Risk assessment model of mining equipment failure based on fuzzy logic. Expert Systems with Applications [online]. 41, 8157-8164. [Viewed 10 January 2019]. Available from: https://isiarticles.com/bundles/Article/pre/pdf/46323.pdf

Rahimdel, M.J. and Bagherpour, R. (2016). Haulage system selection for open pit mines using fuzzy MCDM and the view on energy saving. Neural Comput \& Applic [online]. 29, 187-199. [Viewed 30 January 2019]. Available from: https://link.springer.com/article/10.1007/s00521-016-2562-7

Sabanov, S., Tohver, T., Vali, E. Nikitin, O. and Pastarus, J.R. (2008). Geological aspects of risk management in oil shale mining. Oil Shale [online]. 25 (2), 145-152. [Viewed 23 January 2019]. Available from: https://www.academia.edu/10570467/Geological_Aspects_of_Risk_Management_in_Oil_Shale_Mining

Seidl, M., Tomášková, Y. and Kolman, P. (2011). Alternative options for deploying extraction equipment at large pit quarries. In: 11th International Multidisciplinary Scientific GeoConference SGEM 2011: Conference Proccedings Volume 1 Surveying Geology \& Mining Ecology Management, 20 - 25 June 2011, Albena. Sofia: STEF92 Technology Ltd., 677-684.

Shenkir, W.G. and Walker, P.L. (2006). Enterprise risk management and the strategy risk focused organization. Cost Management [online]. 20, 32-38. [Viewed 27 January 2019]. Available from: https://maaw.info/ArticleSummaries/ArtSumShenkirWalker2006.htm

Singh, R.D. (2004). Principles and practices of modern coal mining. New Delhi: New Age International (P) Limited.

Slivka, V., Grmela, A., Hofrichter, P., Novák, J., Kryl, V., Tichánek, F., Raclavský, K., Dvořáček, J. and Prokop, P. (2002). Těžba a úprava silikátových surovin (The mining and processing of silicate raw materials). Praha: Silikátový svaz.

Soomro, M. A. and Lai, F.W. (2017). Examining a new paradigm of enterprise sustainability risk management. Global Business and Management Research: An International Journal [online]. 9 (1s). [Viewed 3 February 2019]. Available from: https://search.proquest.com/docview/1903433568/fulltextPDF/51868249EDA9440CPQ/1?accountid=269 90

Toraño, J., Torno, S., Alvarez, E and Riesgo, P. (2012) Application of outburst risk indices in the underground coal mines by sublevel caving. International Journal of Rock Mechanics and Mining Sciences [online]. 50, 94-101. [Viewed 8 February 2019]. Available from: https://www.sciencedirect.com/science/article/pii/S1365160912000068

Tworek, P., Tchórzewski, S. and Valouch, P. (2018). Risk management in Coal-mines - methodical proposal for Polish and Czech hard coal mining industry. Acta Montanistica Slovaca [online]. 23 (1), 72-80. [Viewed 28 January 2019]. Available from: https://actamont.tuke.sk/pdf/2018/n1/9tworek.pdf

Vaněk, M., Tomášková, Y., Seidl, M. and Kolman, P. (2012) Identification of the threats, and determining their significance, in stripped overburden transport. In: 12th International Multidisciplinary Scientific GeoConference SGEM 2012: Conference Proccedings Volume 1 Geology, Exploration and Mining, 17 23 June 2012, Albena. Sofia: STEF92 Technology Ltd., 611-618.

Vaněk, M., Tomášková, Y., Straková, A., Špakovská, K. and Bora, P. (2013). Risk Assessment in MiningRelated Project Management. GeoScience Engineering. 59 (3), 47-53.

Van Thueyet, N., Ogunlana, S. O., and Dey, P. K. (2007). Risk management in oil and gas construction projects in Vietnam. International Journal of Energy Sector Management [online]. 1, 175-94. [Viewed 25 February 2019]. Available from: https://www.researchgate.net/publication/242023693_Risk_management_in_oil_and_gas_construction_p rojects_in_Vietnam 